\title{
Kontribusi Dukungan Sosial, Self-Esteem, dan Resiliensi terhadap Stres Akademik Siswa SMA
}

\author{
Ihdan Nizar Aza ${ }^{1}$, Adi Atmoko ${ }^{1}$, Imanuel Hitipeuw ${ }^{2}$ \\ ${ }^{1}$ Bimbingan dan Konseling-Universitas Negeri Malang \\ ${ }^{2}$ Pendidikan Psikologi-Universitas Negeri Malang
}

\begin{tabular}{l}
\hline INFO ARTIKEL \\
\hline Riwayat Artikel: \\
Diterima: 29-03-2019 \\
Disetujui: 20-04-2019 \\
\hline
\end{tabular}

Kata kunci:

social support;

self-esteem;

academic stress;

resilience;

dukungan sosial;

self-esteem;

stres akademik;

resiliensi

\begin{abstract}
ABSTRAK
Abstract: This study aims to determine the contribution of social support, self-esteem, and resilience to the academic stress of high school students with path analysis methods with a sample of 307 students taken by cluster random sampling technique. The research instrument was developed by authors with item validity> 0.30 and reliability> 0.70 . The results showed a direct contribution of social support and self-esteem to the resilience of 0.242 and $0.453 \mathrm{sig}(0.000)$. The direct contribution of social support, selfesteem, and resilience to academic stress were $-0.153,-0.118$, and -0.583 sig $(0.000)$. Indirect contribution of social support and self-esteem to academic stress through the resilience of -0.141 and -0.264
\end{abstract}

\begin{abstract}
Abstrak: Penelitian ini bertujuan untuk mengetahui kontribusi dukungan sosial, selfesteem dan resiliensi terhadap stres akademik siswa SMA dengan metode analisis jalur dengan sampel 307 siswa yang diambil dengan teknik cluster random sampling. Instrumen penelitian dikembangkan penulis dengan validitas butir $>0.30$ dan reliabilitas $>0,70$. Hasil penelitian menunjukkan kontribusi langsung dukungan sosial dan selfesteem terhadap resiliensi sebesar 0.242 dan 0,453 sig (0.000)., kontribusi langsung dukungan sosial, self-esteem, dan resiliensi terhadap stres akademik sebesar - 0.153 , 0.118 , dan -0.583 sig (0.000). Kontribusi tidak langsung dukungan sosial dan selfesteem terhadap stres akademik melalui resiliensi sebesar -0.141 dan -0.264.
\end{abstract}

\author{
Alamat Korespondensi: \\ Ihdan Nizar Aza \\ Bimbingan dan Konseling \\ Universitas Negeri Malang \\ Jalan Semarang 5 Malang \\ E-mail: ihdanaza81@gmail.com
}

Wawancara dengan beberapa guru mengungkap permasalahan stres akademik tampak terutama pada konteks belajar. Siswa memiliki kecenderungan stres pada setiap mendekati ujian terutama siswa yang memiliki hubungan sosial rendah. Stres akademik siswa dapat menyebabkan kegagalan studi, misalnya dilaporkan media sebanyak 74 siswa jenjang SMA tidak melanjutkan pendidikannya atau drop out di tahun akhir sekolahnya (Suara Surabaya, 2016). Perhatian yang kurang terhadap stres akademik akan mengakibatkan permasalahan serius. Stres yang dialami siswa secara bertahap akan menurunkan respon adaptif mereka (Gupchup, Gireesh V. Borrego, Matthew E. Konduri, 2004). Selain itu, stres juga memengaruhi performa siswa (Trockel et al., 2017). Ada kontribusi signifikan stres terhadap keterlambatan studi peserta didik (Sukma \& Adam, 2016). Stres selain dipengaruhi oleh stressor juga dipengaruhi oleh variabel yang mampu meminimalisir stres tersebut. Semakin tinggi daya tahan siswa terhadap tekanan maka kondisi stres semakin dapat diminimalisir.

Penelitian mengungkap resiliensi mampu meminimalisir dan terbukti memiliki efek protektif terhadap kondisi stres maupun depresi terhadap lingkungan yang sulit dan penuh tekanan (Shatté, Perlman, Smith, \& Lynch, 2017). Siswa yang memiliki resiliensi rendah cenderung beresiko gagal. Siswa yang resilien memiliki karakteristik yang secara psikologis lebih sehat, seperti sifat optimistik, dinamis, bersikap antusias terhadap berbagai hal yang ditemuinya dalam hidup termasuk kondisi stres (Tugade \& Fredrickson, 2004). Resiliensi mampu berperan sebagai kemampuan untuk bangkit dengan sukses walaupun mengalami situasi penuh risiko dan tekanan yang tergolong parah (Nasution, 2011). Selain itu, resiliensi dianggap sebagai kemampuan untuk mencapai transformasi diri dan mendapatkan kekuatan ketika mengalami adversity Grotberg (Nasution, 2011). Hasil penelitian lain mengungkap bahwa semakin tinggi kemampuan resiliensi siswa maka semakin rendah stres yang dialaminya (Azzahra, 2017).

Setiap individu baik orang dewasa maupun anak-anak memiliki potensi meminimalisir stres atau peluang untuk menjadi individu yang resilien. Resiliensi bukan faktor bawaan genetik, setiap individu memiliki potensi resilien bahkan kemampuan resiliensi merupakan hal yang dapat diubah, ditumbuhkan, bahkan ditiadakan (Nasution, 2011). Namun, kemampuan tersebut tidak tumbuh begitu saja dalam diri seseorang. Potensi resilien pada setiap siswa harus dikembangkan agar dapat terwujud secara maksimal. Resiliensi pada setiap siswa bergantung pada faktor internal maupun eksternal. Faktor 
eksternal salah satunya adalah seberapa besar dukungan sosial yang didapat individu dari lingkungan sosialnya dan faktor internal yakni bagaimana individu tersebut mempersepsi dan menilai dirinya atau self-esteem (Desmita, 2006).

Dukungan sosial memoderasi kerentanan genetik dan lingkungan dan memberikan kemampuan resiliensi terhadap stres (Ozbay et al., 2007). Penelitian mengungkap kecenderungan remaja yang memiliki dukungan sosial positif memiliki resiliensi yang lebih tinggi dibanding remaja yang memiliki dukungan sosial negatif (Mulia, Elita, \& Woferst, 2014). Selain itu, menciptakan lingkungan belajar yang nyaman dan suportif, hubungan yang nyaman antara guru, siswa dan sesama siswa, menciptakan lingkungan belajar yang nyaman di kelas merupakan salah satu pendekatan untuk meningkatkan resiliensi siswa (Cahill, Beadle, Farrelly, Forster, \& Smith, 2015). Dukungan sosial selain dianggap memiliki kontribusi terhadap resiliensi, juga memiliki efek langsung terhadap kondisi stres siswa. Penelitian menunjukkan bahwa lingkungan pertemanan di sekolah yang sehat dapat melindungi siswa dari kondisi buruk dan berkontribusi pada kompetensi siswa yang beresiko gagal, lingkungan sosial disekolah yang sehat memberikan dukungan bagi siswa dan memberikan harapan yang tinggi untuk prestasi siswa (Armstrong, Birnie-Lefcovitch, \& Ungar, 2005).

Faktor internal siswa seperti self esteem juga berkontribusi terhadap resiliensi. Penelitian mengungkap terdapat korelasi positif self-estem terhadap resiliensi yang artinya peningkatan self-esteem akan diikuti dengan peningkatan resiliensi juga (Utami, 2017). Hal tersebut diperkuat dengan hasil wawancara dengan salah satu guru BK SMA Kediri mengungkap siswa yang memiliki gaya berpikir positif terhadap dirinya cenderung bersemangat dan mampu memenuhi tuntutan sehari-hari. Self-esteem sebagai representasi siswa terhadap dirinya adalah cara berpikir dalam memaknai diri merupakan salah satu faktor yang sangat berperan terhadap berkembangnya potensi resilien. Siswa dengan gaya berpikir positif cenderung memiliki harapan dan mampu untuk bersikap resiliensi. Thinking style pada seseorang menentukan tingkat resiliensi dimana self-esteem merupakan cara pandang siswa dalam memaknai dirinya yang juga ditentukan oleh gaya berpikirnya/thinking style (Nasution, 2011). Selfesteem juga memiliki kontribusi langsung terhadap stres pada siswa. Siswa dengan cara pandang positif cenderung memiliki strategi koping efektif dalam menghadapi stres. Hasil penelitian mengungkapkan bahwa siswa yang memiliki self-esteem tinggi cenderung memiliki resiliensi yang tinggi dan memiliki strategi menghadapi stres yang baik (Dumont \& Provost, 1999).

Pertanyaan yang perlu dijawab dari uraian diatas adalah apakah dukungan sosial, self-estem dan resiliensi mampu berkontribusi secara langsung maupun tidak langsung untuk mengurangi stres akademik siswa?,. Pertanyaan tersebut akan dijawab melalui uji hipotesis yang secara khusus di spesifikan menjadi tujuh hipotesis yang menduga (1) Ada pengaruh positif langsung dukungan sosial terhadap kemampuan resiliensi siswa, (2) Ada pengaruh positif langsung self-esteem terhadap kemampuan resiliensi siswa, (3) Ada pengaruh negatif langsung dukungan sosial terhadap kondisi stres akademik siswa, (4) Ada pengaruh negatif langsung self-esteem terhadap kondisi stres akademik siswa, (5) Ada pengaruh negatif langsung kemampuan resiliensi terhadap kondisi stres akademik siswa, (6) Ada pengaruh negatif tidak langsung dukungan sosial terhadap stres akademik melalui kemampuan resiliensi siswa, (7) Ada pengaruh negatif tidak langsung self-esteem terhadap stres akademik melalui kemampuan resiliensi siswa.

\section{METODE}

Penelitian ini menggunakan pendekatan kuantitatif dengan desain penelitian deskriptif eksplanasi karena mendeskripsikan dan mencari hubungan kausal antar variabel. Analisis data menggunakan analisis jalur yang merupakan penerapan dari regresi ganda. Populasi penelitian ini adalah siswa SMA Negeri 6 Kota Kediri tahun ajaran 2018/2019 yang berjumlah 1209 siswa. Error tolerance yang digunakan dalam penelitian ini ditentukan sebesar 5\% atau 0,05. Sampel sebanyak 307 siswa yang diambil dengan teknik cluster random sampling. Variabel penelitian meliputi variabel bebas (X), variabel moderat $(\mathrm{Z})$, dan variabel terikat $(\mathrm{Y})$. Variabel bebas $(\mathrm{X})$ meliputi dukungan sosial $\left(\mathrm{X}_{1}\right)$, self-esteem $\left(\mathrm{X}_{2}\right)$. Variabel moderat yakni resiliensi $(\mathrm{Z})$ dan variabel terikat $(\mathrm{Y})$ yakni stress akademik. Instrumen penelitian menggunakan skala dukungan sosial dikembangkan dengan mengacu pada teori House (Smet, 2004), skala self-esteem dikembangkan dari teori Coopersmith (Coopersmith, 2007), skala resiliensi dikembangkan dari teori Reivich \& Shatte (Nasution, 2011), sedangkan skala stres dikembangkan berdasarkan teori Selye (Harjana, 2013). Instrumen diuji empirik dengan pengambilan keputusan valid jika nilai cronbach $\geq 0,3$ (Atmoko, 2012). Nilai reliabilitasi skala dukungan sosial sebesar 0,928 >0,70, skala self-esteem sebesar 0,905 > 0,70 , skala resiliensi sebesar 0,912 >0,70, dan skala stres akademik sebesar 0,904 > 0,70. Data diolah dengan metode statistik deskriptif dan inferensial dengan bantuan software SPSS 23.0. for windows. Analisis statistik deskriptif menggunakan distribusi frekuensi, sedangkan uji inferensial menggunakan regresi ganda. Pengambilan keputusan hipotesis dilakukan dengan melihat nilai signifikasi dari setiap jalur hipotesis tersebut diterima jika nilai signifikasi $<0,05$. Kontribusi dilihat pada koefisien jalur langsung, untuk kontribusi tidak langsung merupakan hasil kali koefisien langsung dari kedua jalur terkait.

\section{HASIL}

Analisis deskriptif menunjukkan rata-rata skor total untuk variabel dukungan sosial adalah 54,5, sedangkan siswa yang memperoleh nilai di atas rata-rata sebanyak 54,1\% atau 142 siswa, sisanya sebanyak 45,9\% atau 165 siswa mempunyai skor di bawah rata-rata. Hal ini menunjukkan bahwa lingkungan sosial siswa memiliki potensi yang besar untuk terciptanya lingkungan 
yang mendorong tumbuhnya dukungan sosial antar satu sama lain. Skor untuk variabel resiliensi memiliki rata-rata hitung 67,3 jumlah siswa yang memiliki nilai di bawah rata-rata sebanyak 130 anak atau 43,3\%, sedangkan 177 siswa atau 56,7 \% sisanya memiliki total skor di atas rata-rata hitung hal ini menjelaskan bahwasanya potensi resiliensi siswa cenderung besar karena jumlah siswa kebanyakan memiliki nilai di atas rata-rata hitung. Skor siswa untuk variabel self-esteem memiliki rata-rata 68,8 sedangkan siswa yang memiliki nilai di bawah rata-rata sebesar 45,6\% atau sebanyak 124 siswa.

Sementara itu, siswa memiliki nilai di atas rata-rata sebesar 54,4 \% atau sebanyak 183 siswa yang berati skor selfesteem siswa baik karena jumlah yang berada di atas rata-rata. Nilai rata-rata hitung untuk variabel stres akademik sebesar 31,7, sedangkan jumlah siswa yang memiliki skor di bawah rata-rata sebanyak 186 siswa dan siswa yang memiliki nilai di atas ratarata sebanya 121 siswa hal ini berarti bahwa kecenderungan skor siswa berada di bawah rata-rata hitung atau mayoritas stres akademik siswa rendah. Namun, bukan berarti tidak terjadi permasalahan stres akademik di siswa hal ini masih memerlukan penelitian lebih lanjut. Data penelitian telah memenuhi asumsi normalitas, heteroskedastisitas, dan multikolinieritas. Untuk lebih detail untuk memahami hasil analisis jalur SPSS 23.0 for Windows, berikut disajikan pada tabel 1.

Tabel 1. Hasil Interpretasi Koefisien Jalur I dan II

\begin{tabular}{lcccccc}
\hline \multirow{2}{*}{ Variabel } & \multirow{2}{*}{ Konstanta } & $\begin{array}{c}\text { Koefisien } \\
\text { Jalur }\end{array}$ & Langsung & Tidak Langsung & Total & Signifikasi \\
\cline { 5 - 6 } $\mathrm{X}_{1} \rightarrow \mathrm{Z}$ & 22.906 & 0,242 & 0,242 & - & 0,242 & 0,000 \\
\hline $\mathrm{X}_{2} \rightarrow \mathrm{Z}$ & 22.906 & 0,453 & 0,453 & - & 0,453 & 0,000 \\
\hline $\mathrm{X}_{1} \rightarrow \mathrm{Y}$ & 87.487 & $-0,153$ & $-0,153$ & - & $-0,153$ & 0,000 \\
\hline $\mathrm{X}_{2} \rightarrow \mathrm{Y}$ & 87.487 & $-0,118$ & $-0,118$ & - & $-0,118$ & 0,000 \\
\hline $\mathrm{Z} \rightarrow \mathrm{Y}$ & 87.487 & $-0,583$ & $-0,583$ & - & $-0,583$ & 0,000 \\
\hline $\mathrm{X}_{1} \rightarrow \mathrm{Z} \rightarrow \mathrm{Y}$ & 87.487 & - & $-0,153$ & $-0,141$ & $-0,294$ & - \\
\hline $\mathrm{X}_{2} \rightarrow \mathrm{Z} \rightarrow \mathrm{Y}$ & 87.487 & - & $-0,118$ & $-0,264$ & $-0,382$ & - \\
\hline$\rho_{z v}$ & & 0,264 & - & - & 0,264 & - \\
\hline$\rho_{y w}$ & & 0,779 & - & - & 0,779 & - \\
\hline
\end{tabular}

Berdasarkan tabel 1 diketahui nilai signifikasi pada semua jalur yang dirancang mempunyai nilai signifikasi $<0,05$ yang artinya setiap jalur yang dirancang memiliki kontribusi yang presisi dan tidak perlu ada jalur yang dieliminasi pada saat trimming maka dapat disimpulkan model yang ditawarkan adalah model yang layak (fit). Besar kontribusi tidak langsung dukungan sosial $\left(\mathrm{X}_{1}\right)$ terhadap stres akademik $(\mathrm{Y})$ melalui resiliensi $(\mathrm{Z})$ adalah sebesar $(0,242) \mathrm{x}(-0,583)=-0,141$. Sedangkan kontribusi tidak langsung self-esteem $\left(\mathrm{X}_{2}\right)$ terhadap stres akademik $(\mathrm{Y})$ melalui resiliensi $(\mathrm{Z})$ adalah sebesar $(0,453) \mathrm{x}(-0,583)=$ - 0,264. Besarnya koefisien jalur dari variabel tidak teridentifikasi yang memengaruhi nilai variabel $Z=\sqrt{ }(1-0,393)=\sqrt{ } 0,607=$ 0,779 sedangkan besarnya koefisien jalur dari variabel tidak teridentifikasi yang memengaruhi nilai variabel $\mathrm{Y}=\sqrt{ }(1-0,706)=$ $\sqrt{0,294}=0,542$.

Hipotesis dalam penelitian ini terdiri dari tujuh hipotesis khusus. Hipotesis 1 dan 2 menduga variabel bebas $\left(\mathrm{X}_{1}\right)$ dan $\left(\mathrm{X}_{2}\right)$ memiliki kontribusi yang positif pada variabel moderat $(\mathrm{Z})$ hal ini sesuai dengan output regresi blok 1 yang mengungkap bahwa $\left(\mathrm{X}_{1}\right)$ dan $\left(\mathrm{X}_{2}\right)$ memiliki kontribusi positif terhadap $(\mathrm{Z})$ dengan nilai 0,242 dan 0,453 maka hipotesis 1 dan 2 diterima. Hipotesis 3, 4, dan 5 menduga variabel bebas $\left(\mathrm{X}_{1}\right),\left(\mathrm{X}_{2}\right)$, dan $(\mathrm{Z})$ memiliki kontribusi negatif pada variabel $(\mathrm{Y})$ hal ini sesuai dengan output regresi blok II yang mengungkap kontribusi negatif $\left(\mathrm{X}_{1}\right),\left(\mathrm{X}_{2}\right)$, dan (Z) terhadap (Y) masing-masing sebesar (0,153), ( -0,118), dan (-0,583) maka hipotesis 3, 4, dan 5 diterima. Hipotesis kontribusi tidak langsung mencakup hipotesis 6 dan 7. Hipotesis 6 menduga adanya kontribusi negatif tidak langsung $\left(\mathrm{X}_{1}\right)$ terhadap $(\mathrm{Y})$ melalui $(\mathrm{Z})$ yang merupakan hasil kali dari koefisien $\left(\mathrm{X}_{1}\right)$ terhadap $(\mathrm{Z})$ dan $(\mathrm{Z})$ terhadap $(\mathrm{Y})$ yang memenuhi kriteria presisi $0,000<0,05$ yakni $(0,242) \mathrm{x}(-0,583)=$ - 0,141 sedangkan hipotesis 7 menduga adanya kontribusi negatif tidak langsung $\left(\mathrm{X}_{2}\right)$ terhadap $(\mathrm{Y})$ melalui $(\mathrm{Z})$ yang merupakan hasil kali dari koefisien $\left(\mathrm{X}_{2}\right)$ terhadap $(\mathrm{Z})$ dan $(\mathrm{Z})$ terhadap $(\mathrm{Y})$ yang memenuhi kriteria presisi $0,000<0,05$ yakni $(0,453) \mathrm{x}(-$ $0,583)=-0,264$. Nilai kontribusi tidak langsung dari hipotesis 6 dan 7 masing-masing sebesar - 0,141 dan - 0,264 dengan keputusan diterima karena arah kontribusi juga sesuai dengan praduga yang ditawarkan. 


\section{PEMBAHASAN} (Gambar 1).

Hubungan antar variabel pada model yang ditawarkan pada penelitian ini dapat dipahami pada diagram teoritik

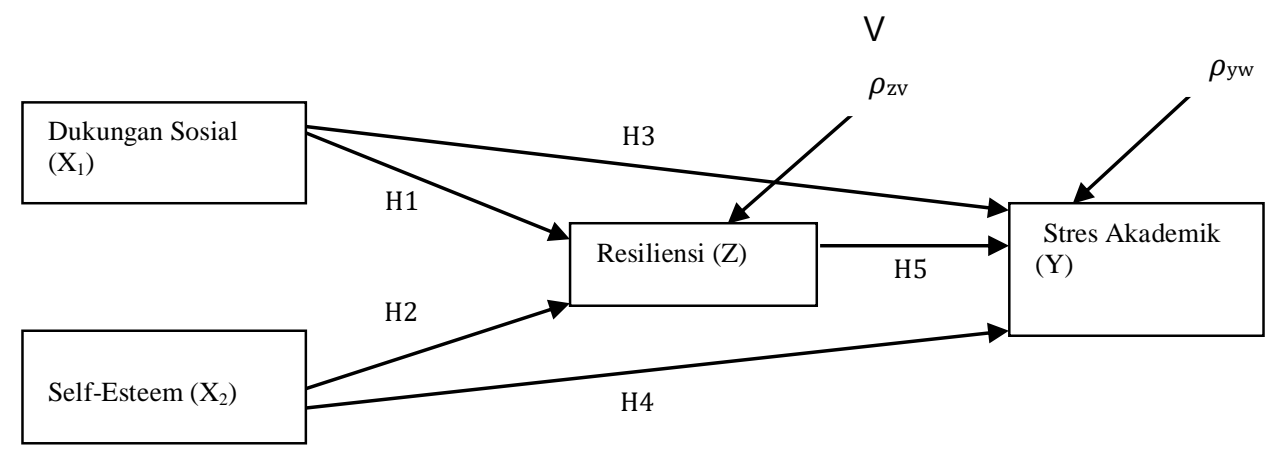

\section{Gambar 1. Diagram Teoritik}

Hasil analisis data mengungkap nilai signifikasi pada setiap jalur masing-masing sebesar 0,000 yang berarti tidak ada jalur yang perlu dielimiasi sehingga didapatkan diagram yang didukung data empirik (Gambar 2).

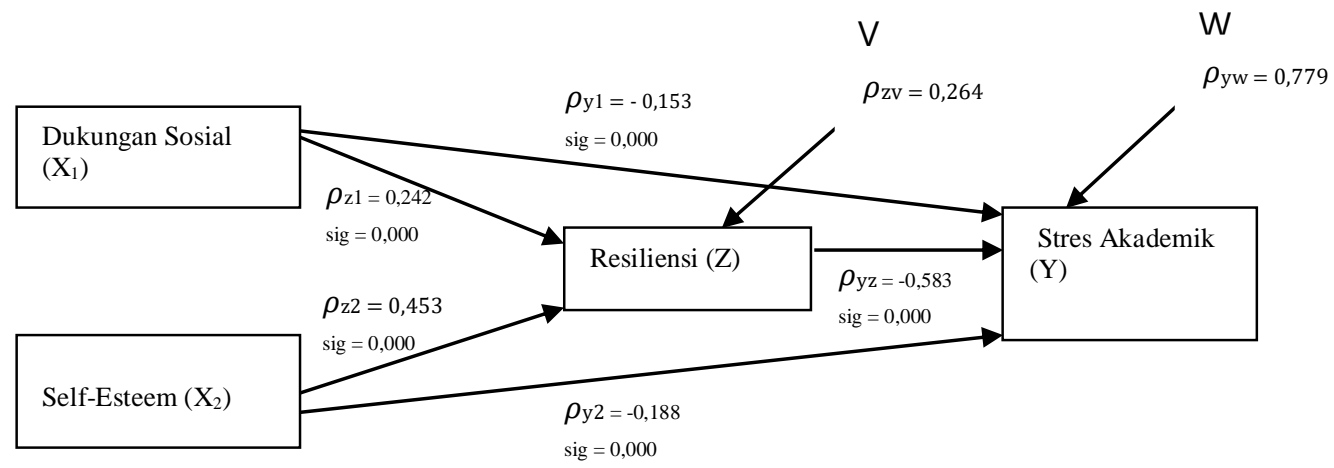

Gambar 2. Diagram Empirik

\section{Hipotesis 1}

Hasil uji hipotesis 1 menunjukkan dukungan sosial memiliki kontribusi positif terhadap resiliensi siswa artinya dukungan sosial yang diperoleh dari orang sekitar menjadi potensi yang relevan untuk mengembangkan potensi resilien pada setiap siswa. Temuan penelitian lain mengungkap dukungan sosial berkontribusi terhadap adaptasi siswa (Fabio \& Kenny, 2015). Dukungan sosial mampu menghadirkan kehangatan dan ketenangan secara emosional sehingga siswa memiliki kekuatan lebih dalam berkembang menjadi siswa yang resilien. Pemanfaatan dukungan sosial sebagai sarana meningkatkan resiliensi sangat realistis mengingat dukungan sosial merupakan faktor eksternal yang dapat dikondisikan.

Temuan kontribusi positif signifikan dukungan sosial terhadap resiliensi siswa di lingkungan sekolah menjelaskan bahwa penciptaan lingkungan belajar yang kooperatif lebih bermanfaat dari kompetitif. Lingkungan belajar yang kooperatif cenderung mendorong siswa saling bekerjasama dan terlibat secara emosional dalam memecahkan permasalahan sehingga mendorong terciptanya lingkungan yang memunculkan dukungan sosial antar siswa dan siswa dengan potensi dukungan sosial yang rendah cenderung memiliki ruang untuk memperoleh dukungan sosial. Sedangkan, lingkungan yang kaku dan bersifat kompetitif akan mempersempit sumber dukungan sosial yang didapat siswa dari teman sebaya dan membatasi perkembangan potensi kemampuan resiliennya. 


\section{Hipotesis 2}

Pengujian hipotesis 2 dalam penelitian ini menunjukkan bahwa self-esteem memiliki kontribusi positif yang signifikan terhadap resiliensi dengan koefisien sebesar 0,453. Penelitian lain mengungkap terdapat korelasi positif self-estem terhadap resiliensi yang artinya peningkatan self-esteem akan diikuti dengan peningkatan resiliensi (Utami, 2017). Kemampuan resiliensi sebagai adaptasi positif merupakan kemampuan yang berguna bagi siswa dalam menempuh studi dan ada beberapa masalah siswa dalam bimbingan dan konseling yang berkaitan dengan permasalahan resiliensi tersebut maka upaya untuk meningkatkan kemampuan resiliensi perlu untuk dipelajari oleh konselor. Temuan kontribusi positif dan signifikan self-esteem terhadap resiliensi ini mendukung konselor menggunakan pendekatan positif dalam melakukan intervensi pada siswa. Penggunaan pendekatan positif akan mendorong siswa memiliki gaya berpikir optimis sehingga mampu mendorong self-esteem dan berdampak pada kemampuan resiliennya. Sebaliknya menggunakan pendekatan mekanistik akan membuat siswa cenderung bersifat pesimistik. Sebagai contoh siswa yang mendapat hukuman akan merasa dirinya tidak berguna dan dibenci oleh lingkungan sehingga siswa tersebut semakin turun self-esteemnya dan diikuti pula dengan kemampuan resilien sulit berkembang. Sebaliknya, penggunaan pendekatan positif dalam menanggani masalah siswa akan mendorong siswa semakin yakin tentang potensi dirinya.

\section{Hipotesis 3}

Uji hipotesis 3 menunjukkan dukungan sosial memiliki kontribusi negatif signifikan terhadap stres akademik siswa dengan nilai koefisien sebesar -0,153 yang berarti berarti dukungan sosial dapat menurunkan stres akademik secara presisi. Temuan ini juga diperkuat hasil penelitian yang mengungkap siswa yang memiliki kecenderungan stres akademik adalah siswa yang memiliki dukungan sosial rendah (Wenz-gross \& Siperstein, 1998). Selain itu, penelitian lain mengungkap tingginya level dukungan sosial dapat menjelaskan minimnya stres akademik yang dialami peserta didik (Friedlander et al., 2014). Hasil penelitian ini mendukung pemanfaatan dukungan sosial sebagai penanganan masalah stres akademik di sekolah oleh konselor terutama pada konteks penelitian dilakukan sehingga konselor tidak hanya fokus pada penyebab stres atau stresor yang dirasa terlalu personal dan dalam kondisi tertentu sulit untuk dikondisikan dan dijangkau. Konselor secara kreatif dapat menciptakan stimulasi atau modifikasi variabel dukungan sosial untuk menurunkan permasalahan stres akademik pada siswa sehingga dapat dicapai penanganan yang efektif dan memudahkan.

Temuan kontribusi negatif dukungan sosial terhadap stres akademik siswa menjelaskan pentingnya memfasilitasi dukungan sosial bagi siswa. Cara paling efektif untuk membantu siswa dari risiko permasalahan dan putus sekolah adalah dengan menciptakan lingkungan penuh dukungan untuk siswa (Wehlage, G. G, Rutter, R.A, Smith, G.A, Lesko, N., Fernandez, 1989). Pendidik baik guru maupun konselor di sekolah dapat memberi stimulasi agar terciptanya lingkungan penuh dukungan sehingga dapat meminimalisir stres akademik yang dialami siswa. Temuan ini sekaligus menjelaskan banyaknya siswa yang sibuk dengan kegiatan di luar tujuan belajar sebagai bentuk stres akademik adalah karena suasana belajar di sekolah kurang memunculkan dukungan sosial, ini dapat dicontohkan dengan gaya intervensi guru yang sering memarahi siswa jika tidak memahami pelajaran akan mendorong siswa semakin tidak nyaman dengan di kelas karena pendidik tidak mengakomodasi dukungan sosial bagi siswa.

\section{Hipotesis 4}

Hipotesis 4 dalam penelitian ini diterima yang artinya terdapat kontribusi negatif signifikan self-esteem terhadap stres akademik siswa dengan koefisien $-0,118$ yang artinya peningkatan pada variabel self-esteem akan diikuti juga dengan penurunan stres akademik pada siswa begitu juga sebaliknya. Temuan ini mendukung temuan lain mengungkap tingginya selfesteem siswa diikuti dengan minimnya stres akademik pada subjek yang sama (Ko, Lee, Kang, Hur, \& Lee, 2013). Variabel stres akademik dapat menyebabkan kegagalan siswa dalam menempuh studi, temuan ini sekaligus menjelaskan bagaimana harus bersikap untuk meminimalisir stres akademik yang dapat dilakukan dengan mempertimbangkan variabel self-esteem.

Konselor dan guru bimbingan dan konseling yang membawahi aspek psikologis dalam melakukan tugasnya di sekolah dapat mempertimbangkan hasil temuan bahwa self-esteem mampu berkontribusi negatif pada stres akademik dalam menangani stres akademik siswa. Seperti yang kita tahu bahwa self-esteem adalah representasi diri dari sudut pandang internal siswa terhadap dirinya, siswa dengan sudut pandang yang positif tentu memiliki keyakinan bahwa dirinya penuh potensi dan layak untuk sukses dalam menempuh pendidikan sebaliknya siswa yang memiliki pandangan negatif tentang dirinya cenderung bersifat pesimistik. Sebagai konselor, memiliki sudut padang bahwa siswa penuh potensi jauh lebih penting dibandingkan melihat tuntutan lingkungan yang belum terpenuhi oleh siswa sehingga pendekatan yang memfasilitasi peningkatan self-esteem dapat dicapai. Penanganan siswa oleh konselor yang cenderung menuntut aspek disiplin tanpa mempertimbangkan hal lain juga berkaitan dengan temuan ini.

Konselor atau guru bimbingan dan konseling seringkali menjadi instrumen sebagai pihak yang menegakkan tata tertib di sekolah. Hal ini sangat berbahaya karena justru bersifat tidak mendukung self-esteem dan mendorong stres akademik siswa. Siswa yang harusnya merasa terfasilitasi justru merasa sebagai target buronan akibatnya persepsi terhadap diri mereka semakin 
turun, menjadi lebih pesimistik, tidak percaya diri dan merasa tidak mampu menjadi siswa yang kompeten. Penurunan selfesteem tersebut menjadikan peluang tingginya stres akademik pada siswa, seperti mereka takut dengan sekolah, anti terhadap bimbingan dan konseling bahkan memilih membolos daripada datang ke sekolah.

\section{Hipotesis 5}

Hasil uji hipotesis 5 menunjukkan bahwa resiliensi memiliki kontribusi negatif yang signifikan resiliensi terhadap stres akademik siswa artinya semakin tinggi kemampuan resiliensi siswa akan diikuti dengan rendahnya stres akademik siswa tersebut. Temuan ini juga didukung dengan temuan lain yang mengungkap terdapat kontribusi negatif yang signifikan resiliensi terhadap kondisi stres peserta didik (Azzahra, 2017). Resiliensi merupakan faktor paling tepat untuk memprediksi penyesuaian di lingkungan belajar (Rahat, 2016). Hasil analisis regresi menunjukkan koefisien -0,583 yang jika dibandingkan dengan koefisien dukungan sosial dan self-esteem koefisien resiliensi ini jauh lebih besar. Jadi, variabel resiliensi memiliki efek lebih besar untuk menurunkan stres akademik siswa jika dibandingkan dengan variabel dukungan sosial dan self-esteem. Kontribusi resiliensi yang besar dapat terjadi karena resiliensi sebagai kemampuan adaptasi positif mampu berfungsi menjadi imunitas terhadap kondisi stres bahkan resiliensi memiliki efek protektif terhadap kondisi stres dan depresi terhadap lingkungan yang sulit dan penuh tekanan (Shatté, Perlman, Smith, \& Lynch, 2017).

Hasil penelitian ini dapat menjadi acuhan bimbingan dan konseling di sekolah dalam menangani variabel stres akademik siswa disekolah terutama dalam konteks penelitian dilakukan. Penanganan maslah stres akademik siswa tidak harus dengan intervensi pada stressor yang dialami. Stressor sangat terkait dengan dunia internal siswa yang dalam dan sulit untuk dijangkau maupun diberikan intervensi. Temuan bahwa kemampuan resiliensi dapat menjadi imunitas terhadap stres akademik memberikan jalan lain bagi bimbingan dan konseling dalam menangani permasalahan stres akademik di sekolah yaitu dengan meningkatkan resiliensi siswa. Pertimbangan resiliensi dapat menjadi upaya preventif yang dapat dilakukan oleh bimbingan dan konseling dalam menangani masalah stres akademik. Selain itu, meningkatkan imunitas jauh lebih memandirikan siswa dan membuat siswa lebih mudah beradaptasi dengan permasalahan baru tentang stres akademik.

\section{Hipotesis 6}

Hasil uji hipotesis 6 menunjukkan terdapat kontribusi negatif dukungan sosial terhadap stres akademik melalui resiliensi siswa dengan besar koefisien - 0,141. Temuan ini menunjukkan bahwa secara tidak langsung dukungan sosial juga mempunyai kontribusi terhadap stres akademik siswa karena terlibatnya kemampuan resiliensi siswa. Temuan ini menjelaskan bahwa dalam sistem sekolah pemeliharaan lingkungan yang memunculkan dukungan sosial amat penting dan berkontribusi pada tingkat stres siswa. Lingkungan yang penuh dengan persaingan sehingga siswa dituntut untuk berkompetisi dalam belajar akan membuat mereka bersifat individual dan cenderung tidak terlibat secara emosional anatar satu dan yang lain. Kurangnya keterlibatan secara emosional antar siswa membuat potensi resilien mereka tidak berkembang sehingga rentan terhadap permasalahan stres akademik. Lingkungan yang kompetitif ini bagi sebagian siswa memang wajar dan tidak memiliki efek yang besar dalam prestasinya namun, bagi sebagian kecil siswa yang tidak mampu berkompetisi akan menyebabkan mereka mengalami tekanan yang sangat berarti dan dapat memicu kegagalan karena tingkat stres akademik yang besar. Lingkungan yang kompetitif dalam belajar memang tidak seluruhnya dapat dihindari. Konselor sebagai pihak yang terkait dengan aspek psikologi siswa dapat menciptakan lingkungan yang kooperatif dan penuh keterlibatan secara emosional di luar situasi belajar sehingga meskipun pada kondisi belajar mereka memiliki lingkungan yang kompetitif namun di luar itu siswa masih dapat terlibat secara emosional untuk meningkatkan dukungan sosial mereka.

Keterlibatan pendidik dan sistem sekolah juga sangat penting dalam menghadirkan dukungan sosial. Pendidik yang memiliki keterlibatan sosial tinggi dan temperamen yang rendah membuat siswa memiliki resiliensi yang tinggi pada aspek kompetensi perilaku dan sosial (Smith \& Ph, 1995). Pendidik yang sekedar memberikan materi belajar tanpa terlibat dalam hubungan sosial yang bermakna dapat menjelaskan rendahnya kemampuan siswa mengakomodasi tuntutan sekitar dan menimbulkan perilaku jauh dari harapan yang mengindikasikan stres akademik. Pendidik dan sistem sekolah yang tidak memenuhi dukungan sosial siswa menjadi alasan yang kuat maraknya siswa mengikuti bimbingan belajar di luar sekolah. Siswa yang merasa dukungan dari guru dalam belajar cukup memfasilitasi tentu tidak perlu mencari sumber dukungan lain, seperti mengikuti bimbingan belajar di luar sekolah. Siswa akan senang dengan lingkungan belajar di sekolah sehingga tidak perlu mengikuti bimbingan belajar di luar, bagi siswa yang memiliki bekal resiliensi cukup masih memiliki inisiatif untuk mencari dukungan dari lembaga lain di luar sekolah namun sebagian lain ini memicu kondisi stres akademik. Jadi, maraknya siswa mengikuti bimbingan belajar di luar sekolah menjadi gambaran bahwa siswa tidak cukup mendapat dukungan sosial dari guru maupun sistem sekolah. 


\section{Hipotesis 7}

Hasil uji hipotesis 7 menunjukkan terdapat kontribusi negatif self-esteem terhadap stres akademik melalui resiliensi siswa dengan besar koefisien - 0,264 yang berarti peningkatan self-esteem pada siswa akan diikuti dengan penurunan stres akademik siswa karena meningkatnya kemampuan resiliensi siswa. Temuan serupa menjelaskan bahwa siswa yang memiliki self-esteem tinggi cenderung memiliki resiliensi yang tinggi dan memiliki strategi menghadapi stres yang baik (Dumont \& Provost, 1999). Secara teoritik kontribusi tidak langsung ini dapat dijelaskan bahwa siswa dengan sudut pandang yang positif terhadap dirinya cenderung meyakini potensi dirinya mampu untuk menghadapi berbagai tantangan $\mathrm{z}$ dan mendorong kemampuan adaptasi positifnya sehingga dalam menghadapi kondisi yang menekan seperti stres akademik mereka cenderung lebih mudah menyesuaikan.

Temuan kontribusi negatif tidak langsung self-esteem terhadap stres akademik melalui resiliensi merupakan gambaran bahwa pentingnya sudut padang positif oleh konselor dalam melihat siswa sebagai individu yang memiliki banyak potensi tidak hanya sebatas berkontribusi kepada stres akademik siswa seperti yang telah dijelaskan di sub-bab sebelumnya namun juga terkait dengan kemampuan resiliensi siswa. Jadi, sudut pandang positif oleh konselor juga mendorong siswa untuk lebih bersifat resilien dan secara mandiri dapat mengatasi stres akademik.

Pendidik dan sistem sekolah juga sangat terkait dengan temuan ini. Pembentukan kelas khusus seperti kelas olimpiade baik bagi reputasi sekolah namun jika tidak benar-benar diperhatikan maka dapat menjadi masalah bagi sebagian siswa di sekolah tersebut. Adanya kelas khusus atau unggulan seperti kelas olimpiade membuat siswa kelas reguler akan merasa mereka adalah siswa yang biasa-biasa saja tidak mampu melambung tinggi dan cenderung tersisihkan terlebih lagi jika pendidik memerlakukan berbeda saat mengajar maupun memberikan intervensi. Hal ini akan mengakibatkan siswa reguler semakin turun self-esteemnya sehingga diikuti dengan turunnya minat belajar sebagai bentuk penurunan resiliensi siswa. Akibatnya, siswa akan sibuk dengan hal lain di luar tujuan belajar sekolah, seperti sibuk dalam hubungan pertemanan membentuk sebuah gank, membuat siswa lebih menyukai kehidupan di luar sekolah sehingga mereka membolos dan kegiatan-kegiatan lain sebagai bentuk terjadinya stres akademik pada siswa.

\section{SIMPULAN}

Berdasarkan hasil analisis teori cognitive aprasial dan teori resiliensi terhadap data deskriptif, kontribusi setiap variabel, dan model yang ditawarkan, maka dapat disimpulkan bahwa model teoritik stres akademik siswa di sekolah terbukti layak mendapat dukungan data empiris. Model tersebut dapat dirumuskan sebagai berikut. Kondisi stres akademik siswa dipengaruhi oleh dukungan sosial, self-esteem dan kemampuan resiliensinya. Resiliensi siswa ditentukan oleh dukungan sosial dan self-esteem. Dengan demikian, resiliensi memengaruhi stres akademik secara langsung dan dukungan sosial, self-esteem memengaruhi stres akademik secara langsung maupun tidak langsung melalui resiliensi. Rumusan tersebut mendukung konsep teori cognitive aprasial dan teori resiliensi yang menjadi landasan penelitian ini. Konsep yang dimaksud adalah sama-sama mengakui peran kognitif sebagai aspek yang menentukan stres akademik.

Konselor dapat mempertimbangkan resiliensi dalam menangani permasalahan stres akademik. Layanan bimbingan dan konseling sebaiknya memfasilitasi terciptanya lingkungan penuh dukungan sosial dan mempertimbangkan aspek-aspek yang memfasilitasi self-esteem siswa. Penciptaan suasana yang penuh ikatan emosional dan hubungan kooperatif antar siswa amat membantu untuk menjaga siswa dari stres akademik, selain itu menjaga hubungan hangat dengan siswa menjadi kunci utama dalam membantu mereka menghindari stres-akademik di sekolah. Penanganan siswa dengan melihat dari segi disiplin dirasa kurang relevan karena akan menurunkan self-esteem siswa dan berdampak pada stres akademik siswa. Pendekatan positif dalam memandang siswa juga amat penting untuk membantu meningkatkan self-esteem siswa. Bagi sekolah hendaknya memiliki sistem yang mendukung terciptanya dukungan sosial dan self-esteem karena jika sistem tidak mendukung tumbuhnya dukungan sosial dan self-esteem akan memengaruhi perilaku pendidik untuk siswa. Pembentukan kelas khusus seperti kelas olimpiade hendaknya mempertimbangkan kelas reguler agar tidak mengalami penurunan self-esteem sehingga tidak berdampak pada stres akademik siswa. Sistem yang mendukung pembelajaran kooperatif juga sangat diperlukan untuk menjaga dan menciptakan lingkungan penuh kehangatan yang mendukung dukungan sosial antar siswa. Bagi peneliti yang akan datang diharapkan dapat mempertimbangkan hasil penelitian ini sebagai dasar pengetahuan berkaitan dengan masalah stres akademik maupun resiliensi siswa di sekolah.

\section{DAFTAR RUJUKAN}

Armstrong, M. I., Birnie-Lefcovitch, S., \& Ungar, M. T. (2005). Pathways Between Social Support, Family Well Being, Quality of Parenting, and Child Resilience: What we Know. Journal of Child and Family Studies, 14(2), 269-281. https://doi.org/10.1007/s10826-005-5054-4

Atmoko, A. (2012). Bahan Ajar Matakuliah Desain dan Analisis Data. In Bahan Ajar Matakuliah. Malang: Pascasarjana Universitas Negeri Malang.

Azzahra, F. (2017). Pengaruh Resiliensi terhadap Distres Psikologis pada Mahasiswa. Jurnal IImiah Psikologi Terapan, 05. 
Cahill, H., Beadle, S., Farrelly, A., Forster, R., \& Smith, K. (2015). Building Resilience in Children and Young People: A Literature Review for the Department of Education and Early Childhood Development (DEECD). Retrieved from http://www.education.vic.gov.au/documents/about/department/resiliencelitreview.pdf

Coopersmith, S. (2007). The antecedents of self-esteem. Consulting Psychologists Press.

Desmita. (2006). Psikologi Perkembangan. Bandung: PT. Remaja Rosda Karya.

Dumont, M., \& Provost, M. (1999). Resilience in Adolescents: Protective Role of Social Support, Coping Strategies, Selfesteem, and Social Activities on Experience of Stress and Depression. Journal of Youth and Adolescence, $28(3), 343-363$.

Fabio, A. Di, \& Kenny, M. E. (2015). The Contributions of Emotional Intelligence and Social Support for Adaptive Career Progress Among Italian Youth, 42(1), 48-59. https://doi.org/10.1177/0894845314533420

Friedlander, L. J., Reid, G. J., Shupak, N., Cribbie, R., Student, C., June, M., Cribbie, R. (2014). Social Support, Self-Esteem, and Stress as Predictors of Adjustment to University Among First-Year Undergraduates Social Support, 48(3), $259-274$. https://doi.org/10.1353/csd.2007.0024

Gupchup, Gireesh V. Borrego, Matthew E. Konduri, N. (2004). The Impact of Student Life Stress on Health Relatedquality of Life Among Doctor of Pharmacy Students. College Student Journal, 38(2), 292-301.

Harjana, A. (2013). Stres Tanpa Distres: Seni Mengolah Stres. Yogyakarta: Kanisus.

Ko, J., Lee, Y. K., Kang, H., Hur, K., \& Lee, Y. (2013). Effects of Self-esteem and Academic Stress on Depression in Korean Students in Health Care Professions Effects of Self-esteem and Academic Stress on Depression in Korean Students in Health Care Professions, (April 2017). https://doi.org/10.12934/jkpmhn.2013.22.1.56

Mulia, L. O., Elita, V., \& Woferst, R. (2014). Hubungan Dukungan Sosial Teman Sebaya terhadap Tingkat Resiliensi Remaja di Panti Asuhan. Jom Psik, 1(2), 1-9.

Nasution, S. M. (2011). Resiliensi: Daya Pegas Menghadapi Trauma Kehidupan. Medan: USU Press.

Ozbay, F., Johnson, D., Morgan, C., Dimoulas, E., Charney, D., \& Southwick, S. (2007). Social Support and Resilience to Stress From Neurobiology to Clinical Practice. Psychiatry (Edgmont), 4, 35-40. Retrieved from https://www.ncbi.nlm.nih.gov/pmc/articles/PMC2921311/\#_ffn_sectitle

Rahat, E. (2016). Coping Styles, Social Support, Relational Self- Construal, and Resilience in Predicting Students ' Adjustment to University Life *, 187-208. https://doi.org/10.12738/estp.2016.1.0058

Shatté, A., Perlman, A., Smith, B., \& Lynch, W. D. (2017). The Positive Effect of Resilience on Stress and Business Outcomes in Difficult Work Environments. Journal of Occupational and Environmental Medicine, 59(2), 135-140. https://doi.org/10.1097/JOM.0000000000000914

Smet, B. (2004). Psikologi Kesehatan. Jakarta: PT. Grasindo.

Smith, J. A. N., \& Ph, D. (1995). Temperament and Stress Resilience in School-Age Children : A Within-Families Study, (February), 168-179. https://doi.org/10.1097/00004583-199502000-00012

Suarasurabaya. (2016). 74 Siswa Jenjang SMA di Lumajang Drop Out Saat UN. Retrieved October 12, 2018, from http://www.suarasurabaya.net/jaringradio/news/2016/169833-74-Siswa-Jenjang-SMA-di-Lumajang-Drop-Out-Saat-UN),

Sukma, A., \& Adam, H. (2016). Studi Empiris Pengaruh Kecerdasan Emosional, Perilaku Belajar, dan STRES Kuliah terhadap Keterlambatan Penyelesaian Studi (Studi pada Mahasiswa S1 Akuntansi Universitas Brawijaya Malang. Jurnal Ilmiah Mahasiswa Fakultas Ekonomi dan Bisnis, 1. http://jimfeb.ub.ac.id/index.php/jimfeb/article/view/707.

Trockel, M. T., Barnes, M. D., Egget, D. L., Trockel, M. T., Barnes, M. D., \& Egget, D. L. (2017). Health-Related Variables and Academic Performance Among First-Year College Students: Implications for Sleep and Other Behaviors, 8481(April). https://doi.org/10.1080/07448480009596294

Tugade, M. M., \& Fredrickson, B. L. (2004). Resilient Individuals Use Positive Emotions to Bounce Back From Negative Emotional Experiences. Journal of Personality and Social Psychology, 86(2), 320-333. https://doi.org/10.1037/00223514.86.2.320

Utami, C. T. (2017). Self-Efficacy dan Resiliensi: Sebuah Tinjauan Meta-Analisis. Buletin Psikologi, $25(1), 54$. https://doi.org/10.22146/buletinpsikologi.18419

Wehlage, G. G, Rutter, R.A, Smith, G.A, Lesko, N., Fernandez, R. (1989). Reducing the Risk: Schools as Communities of Support. New York: The Falmer Press.

Wenz-gross, M., \& Siperstein, G. N. (1998). School- Stress, Social Support, and Adjustment, 65(I), 91-100. 